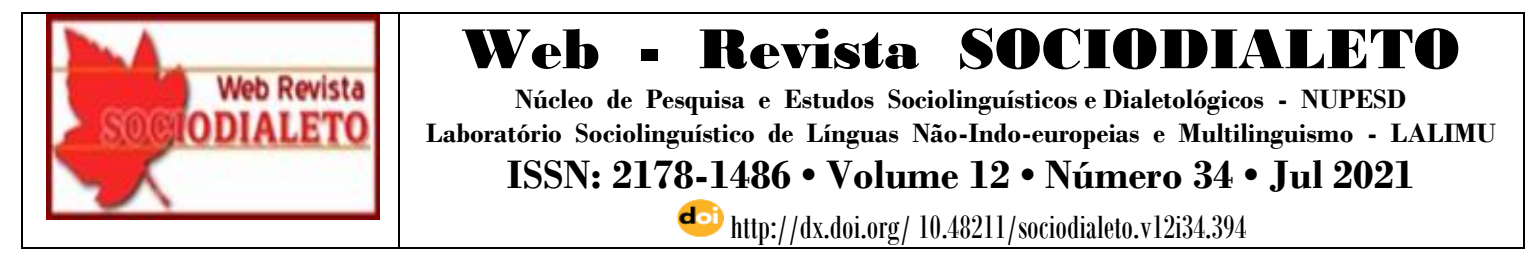

\title{
ENTRE O ENSINAR E O APRENDER PORTUGUÊS: UM ESTUDO ETNOGRÁFICO DA PRÁTICA PEDAGÓGICA NO ENSINO FUNDAMENTAL
}

\section{BETWEEN TEACHING AND LEARNING PORTUGUESE: AN ETHNOGRAPHIC STUDY OF PEDAGOGICAL PRACTICE IN PRIMARY SCHOOLS}

\author{
Darkyana Francisca Ibiapina (PPGEL-UFPI) ${ }^{1}$ \\ darkybiapina@hotmail.com \\ Catarina de Sena Sirqueira Mendes da Costa (UFPI) ${ }^{2}$ \\ costacatarina@uol.com.br
}

\begin{abstract}
RESUMO: Sabendo da importância que assumem a oralidade e a escrita em uma sociedade letrada como a nossa, compreendemos que a prática pedagógica do professor de Língua Portuguesa precisa considerar, em suas atividades diárias, aspectos de ordem técnica, econômica, social, cultural, afetiva e cognitiva, que possibilitem a ampliação da competência comunicativa (oral e escrita) dos alunos, para que a escola possa estar realmente desempenhando seu papel junto à sociedade, no que diz respeito ao ensino de língua. Assim, o nosso objetivo consiste em analisar as estratégias desenvolvidas em sala de aula que favorecem à ampliação da competência comunicativa dos alunos. A análise foi realizada em uma turma de $5^{\mathrm{a}}$ série $/ 6^{\circ}$ ano do Ensino Fundamental de uma escola pública da rede estadual de ensino, localizada no município de Campo Maior - PI. Para a realização deste estudo escolhemos a pesquisa etnográfica como método de investigação, por nos permitir documentar o que realmente acontece no espaço da sala de aula. À luz dos conceitos de Hymes (1972a), sobre competência comunicativa, dos estudos sociolinguísticos de BortoniRicardo (2005, 2017), Faraco $(2008,2015)$ e dos conceitos desenvolvidos por Cazden (1988) sobre as ações de scaffolding, procuramos descrever as ações do cotidiano de sala de aula que possibilitem ampliar as habilidades de comunicação oral e escrita dos educandos. Dentre outros resultados, percebemos que a professora através da leitura e interpretação oral e escrita de um texto do gênero "carta de solicitação", ao tempo em que proporciona o conhecimento das características do gênero, vai possibilitando o conhecimento de quando é adequado falar ou não, sobre o que falar e com quem, quando, onde e como, ou seja, enriquecendo as experiências comunicativas dos alunos, como uma das formas de favorecer a ampliação da competência comunicativa de que fala Hymes.
\end{abstract}

PALAVRAS-CHAVES: Competência Comunicativa. Prática Pedagógica. Estratégias.

ABSTRACT: Knowing the importance of orality and writing in a literate society like ours, we understand that the pedagogical practice of the Portuguese language teacher needs to consider, in his daily activities, technical, economic, social, cultural, affective and cognitive aspects, that allow the expansion of the communicative competence (oral and written) of the students, so that the school can really be playing its role with the society, with regard to the teaching of language. Thus, our goal is to analyze the strategies developed in the classroom that favor the expansion of students' communicative competence. The analysis was carried out in a class of 5th grade / 6th grade of elementary school in a public school in the state school system, located in the municipality of Campo Maior - PI. In order to carry out this study, we chose ethnographic research as an investigation method, as it allows us to document what really happens in the

\footnotetext{
${ }^{1}$ Doutoranda em Letras pelo Programa de Pós-Graduação em Letras da UFPI.

${ }^{2}$ Professora Doutora do Programa de Pós-Graduação em Letras da UFPI.
} 


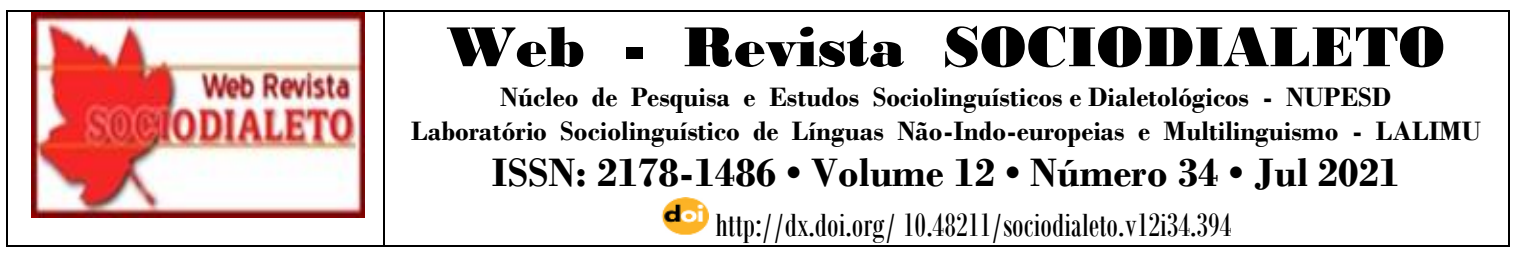

classroom space. In order to carry out this study, we chose ethnographic research as an investigation method, as it allows us to document what really happens in the classroom space. In the light of the concepts of Hymes (1972a), on communicative competence, the sociolinguistic studies of Bortoni-Ricardo (2005, 2017), Faraco $(2008,2015)$ and the concepts developed by Cazden (1988) about scaffolding actions, we try to describe the actions of the daily classroom that make it possible to expand the students' oral and written communication skills. Among other results, we noticed that the teacher through the reading and oral and written interpretation of a text of the genre "letter of request", while providing knowledge of the characteristics of the genre, allows for the knowledge of when it is appropriate to speak or not, about what to talk about and with whom, when, where and how, that is, enriching the students' communicative experiences, as one of the ways to favor the expansion of the communicative competence that Hymes talks about.

KEYWORDS: Communicative Competence. Pedagogical Practice. Strategies.

\section{Introdução}

A sociedade vem se transformando aceleradamente, tendo como consequência o aumento das exigências e dos desafios impostos à escola e aos professores. Nesse processo, ter competência para ensinar requer muito mais do que seguir instruções dadas por outros, é preciso ser capaz de transformar informações em conhecimentos, pois, pensamento, compreensão e ação constituem fatores de desenvolvimento pessoal, social e profissional. (BANDEIRA, 2016). Desse modo, a prática pedagógica constitui desafio constante, especialmente, quando pretendemos torná-la objeto de pesquisa.

Nesse contexto, a escola assume o importante papel de promover aos alunos, o acesso aos estilos formais da língua, os quais representam um modo de ascensão e mobilidade social que poderão refletir na integração do indivíduo na sociedade de forma mais privilegiada. No entanto, são muitas as críticas de que a escola não vem desempenhando adequadamente esse papel, pois os alunos chegam ao final do Ensino Fundamental e às vezes até do Ensino Médio sem dominar a tão almejada "variedade padrão".

A preocupação dos estudiosos com a educação, especialmente a dos sociolinguistas da vertente educacional e etnográfica, têm contribuído significativamente nos últimos anos para o desenvolvimento dessa área, principalmente em relação ao ensino de língua materna. Merecendo destaque autores como: Labov (1972b), J. Cook-Gumpers (1987), Hymes (1974a e 1972b), Erickson (1987) e no Brasil apontamos os estudos de Bortoni-Ricardo (2004, 2005, 2017). 


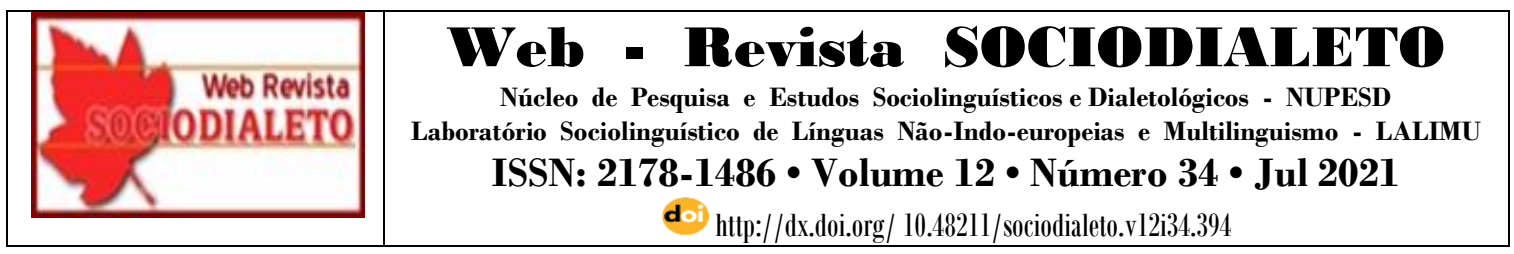

Habilitar os alunos a desempenhar o uso da língua, tanto na modalidade oral quanto escrita, com fluência e segurança, exige uma Prática Pedagógica comprometida não somente com o desenvolvimento de atividades relacionadas com a leitura e a escrita, mas com o exercício do falar, ouvir, ler e escrever, e, além disso, que considere os aspectos relacionados às condições socioculturais dos alunos e da comunidade em que vivem. Nessa perspectiva, observamos, ao longo da nossa trajetória docente, como a escola, e especialmente as aulas de língua Portuguesa centralizam o ensino da modalidade escrita da língua, como se fosse possível haver uma separação entre oralidade e escrita, assim, o desenvolvimento da oralidade parece que vai se tornando uma preocupação menor à medida que se avança na série de estudo e se tornando sempre uma conseqüência da escrita.

Dessa forma, percebemos que um aspecto indispensável para a ampliação da competência comunicativa dos alunos é a fala, inclusive para a aprendizagem da escrita, pois como afirma Cook-Gumperz (1987), a fala possibilita a reflexão dos processos através dos quais os alunos relacionam o novo conhecimento ao velho. No entanto, esta reflexão depende das relações sociais, do sistema comunicativo que a professora estabelece. Ou seja, falar com os alunos, transmitir informações, responder ao que foi perguntado, deixar os alunos falarem entre si, ordená-los, repreendê-los, são ações escolhidas pelo professor que guiam a interação em sala de aula. Assim como, falar com o professor, contar acontecimentos do cotidiano, da família, ficar em silêncio, pedir uma informação, conversar com os colegas, são ações por parte do aluno que também direcionam a interação e podem revelar informações sobre eles e sobre o que significa para eles as ações que praticam nesse processo de interação e a situação de que participam. (CAJAL, 2001)

Nesse contexto, é importante lembrar que ensinar e aprender são processos de interação dos quais professores e alunos participam, por isso o sucesso de uma vida escolar pode estar relacionado à forma como professores e alunos compartilham convenções sociais e culturais, o que lhes proporcionará, por exemplo, saber quem tem o direito de falar, quando e como fazê-lo. Mais uma vez fica esclarecido o quanto uma 


\begin{tabular}{|c|c|}
\hline $\begin{array}{l}\text { Web } \\
\text { ODIA }\end{array}$ & 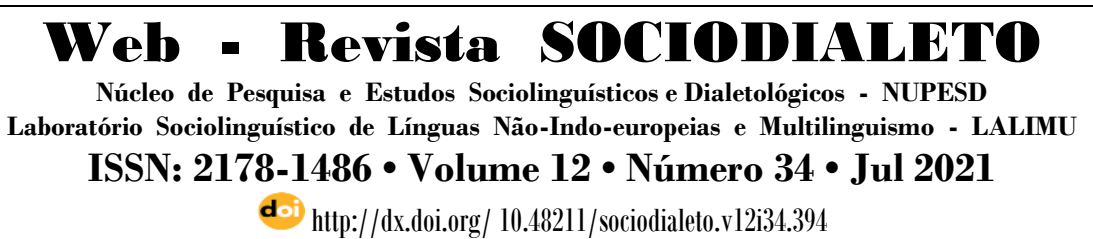 \\
\hline
\end{tabular}

Prática Pedagógica consciente pode contribuir para que ocorra sucesso no ensino de língua materna.

A relevância do tema em questão é demarcada tanto pelos PCN - Parâmetros Curriculares Nacionais para o Ensino de Língua Portuguesa, quanto pela Base Nacional Comum Curricular, documentos elaborados com o objetivo de contribuir para a atualização profissional, curricular e que são diretrizes para o ensino de língua, quando assinalam a necessidade de saber expressar-se nas diferentes situações sociais do exercício da cidadania que se colocam fora do contexto escolar, tais como; as argumentações e opiniões em defesa dos seus direitos, as atividades profissionais, as entrevistas em busca de trabalho.

Diante dessa preocupação evidenciada pelos estudiosos e em especial pela nossa experiência como docente da educação básica, surge a necessidade de realizar essa investigação com o objetivo de analisar, através das tarefas comunicativas da professora e dos alunos, as estratégias desenvolvidas em sala de aula que favorecem a ampliação da competência comunicativa dos alunos. Pretendemos compreender como a partir das atividades desenvolvidas em sala de aula e das concepções da professora como estas estratégias podem contribuir para a ampliação da competência comunicativa dos alunos dos alunos do $6^{\circ}$ ano do Ensino Fundamental de uma escola pública do município de Campo Maior - Pi.

Para a realização dessa investigação utilizamos para a coleta de dados a entrevista informal e a observação participante acompanhada por gravação em áudio e diário de campo. Este tipo de observação se dá através da presença do pesquisador em cenas da vida diária dos membros do grupo social estudado, no nosso caso, a sala de aula.

\section{FUNDAMENTAÇÃO TEÓRICA}

2.1 O conceito de competência comunicativa e sua importância para o ensino de língua materna. 


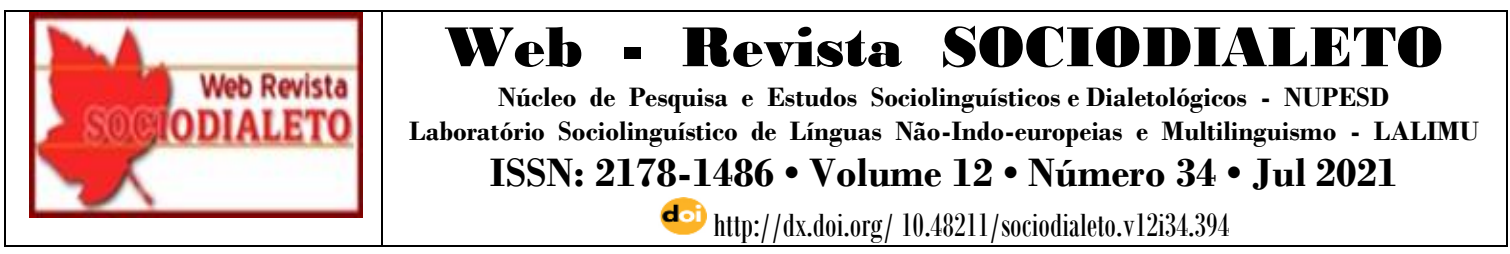

O conceito de competência comunicativa proposto por Dell Hymes (1972a) tem sido extremamente relevante na área de ensino e aprendizagem de línguas. Tal conceito faz parte inclusive do objetivo que se coloca para o ensino de língua materna definido por Traváglia (2002):

O ensino de língua materna se justifica prioritariamente pelo objetivo de desenvolver a competência comunicativa dos usuários da língua (falante, escritor, ouvinte, leitor), isto é, a capacidade do usuário de empregar adequadamente a língua nas diversas situações de comunicação. (TRAVÁGLIA, 2002, p.17).

Além deste, outros autores revisitam constantemente o conceito em questão pela sua atualidade e popularidade nos estudos linguísticos. É importante destacar que aliado ao conceito de competência comunicativa, outros fenômenos, como da variação e mudança linguísticas precisam ser considerados no processo de ensino e aprendizagem de uma língua, no caso específico de Língua Portuguesa, Cyranka (2015, p. 34) questiona: "é possível desestabilizar a tradição do tratamento escolar dado ao "ensino" de português e, efetivamente, construir uma "pedagogia da variação linguística3", conforme propõe Faraco (2008)?”.

Acreditamos que a revolução que queremos para o ensino de língua precisa começar pelo professor. No entanto, para que este consiga fazer das suas aulas um laboratório onde se desenvolvem a reflexão gramatical e a pesquisa linguística e, assim, formar o leitor/produtor de texto competente, crítico e autônomo, é necessário "também conhecer o aluno, saber a que comunidade de fala ele pertence, que valores culturais perpassam suas experiências, que práticas de letramento tem vivenciado" (CYRANKA, 2015, p. 35).

Esses conhecimentos são indispensáveis ao professor de Língua Portuguesa, especialmente quando observamos o que propõe a Base Nacional Comum Curricular para o Ensino Fundamental (BRASIL, 2017), ao destacar que cabe ao componente Língua

\footnotetext{
${ }^{3}$ Faraco e Zilles (2015, p. 9-10) explicam que quando tratam de "pedagogia da variação linguística" não estão propondo "uma pedagogia da língua materna composta de módulos autônomos, mas tão somente estimulando uma reflexão focada nas grandes questões que envolvem a variação linguística no ensino de português" sem desconsiderar uma perspectiva integradora das diferentes dimensões desse ensino.
} 


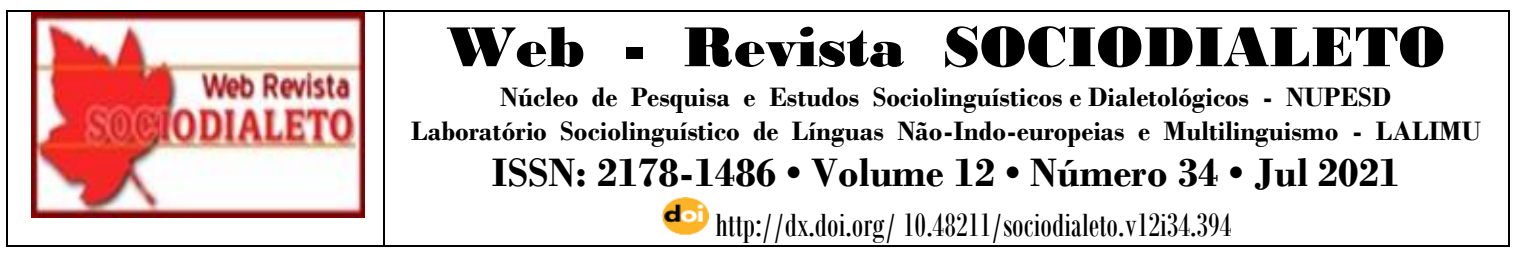

Portuguesa "proporcionar aos estudantes experiências que contribuam para a ampliação dos letramentos, de forma a possibilitar a participação significativa e crítica nas diversas práticas sociais permeadas/constituídas pela oralidade, pela escrita e por outras linguagens." (BRASIL, 2017, p.). Ou seja, espera-se da escola e dos professores que proporcionem aos alunos a ampliação dos recursos linguísticos, por meio da integração das diferentes práticas de linguagem leitura, oralidade, produção de textos oral e escrita e análise linguística e semiótica. Para tanto, o professor não pode abrir mão de um trabalho pautado nos gêneros textuais, suas características e condições de produção.

Diante de tais expectativas, ampliar a competência comunicativa dos alunos tornase tarefa central no ensino de língua. Assim, discutiremos esse conceito, a partir da perspectiva do ponto de vista que será abordado nessa pesquisa, qual seja, o da sociolinguística educacional. Segundo Bortoni-Ricardo (2005, p. 61), nessa perspectiva, "para operar de uma maneira aceitável, um membro de uma comunidade de fala tem de aprender o que dizer e como dizê-lo apropriadamente, a qualquer interlocutor e em quaisquer circunstâncias". Ou seja, esse membro adquire além do conhecimento de um código comum, uma habilidade de usá-lo, através de uma capacidade pessoal denominada por Hymes (1972) “competência comunicativa”.

O conceito de Competência Comunicativa proposto por Dell Hymes (1971), a partir dos estudos realizados no campo da Etnografia da Comunicação, foi determinante para a sociolingüística, por trazer à tona a discussão sobre a noção de Competência Lingüística (capacidade de, com base nas regras da língua, gerar um número infinito de frases gramaticais, conforme a teoria gerativista) proposta por Chomsky (1965). Para o autor esse conceito não dá conta das questões da variação da língua, portanto ele não só reviu como também ampliou tal conceito incluindo nele a noção de "competência social".

Desta forma, o referido autor propõe um novo conceito, o de competência comunicativa, que permite ao falante saber o que dizer e como dizer ao interagir com os diferentes interlocutores, assumindo diferentes papéis sociais e em quaisquer circunstâncias. Para Bortoni-Ricardo (2004), Hymes inclui em seu novo conceito a noção de adequação, ou seja, das normas definidas na cultura do falante que lhe dizem quando e como monitorar seu estilo. Assim, para explicar a produção e interpretação do 


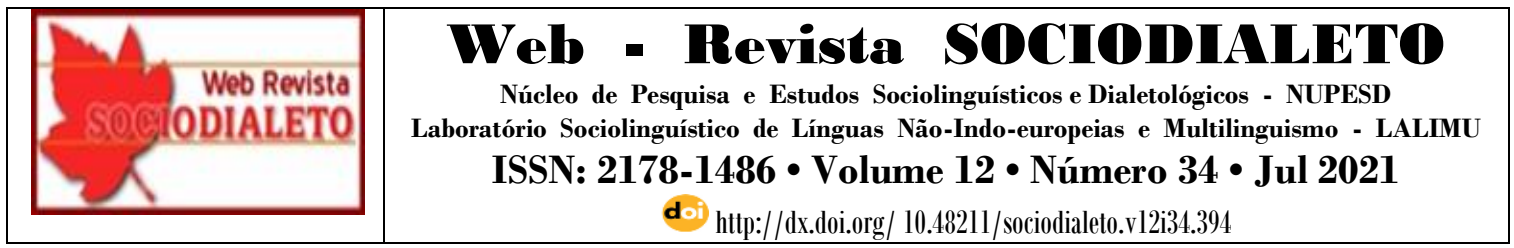

comportamento cultural, uma teoria da competência comunicativa deve explicar o que é formalmente possível, o que é adequado em relação ao contexto, o que é efetivamente realizado.

Além da noção de adequação, outra dimensão muito importante no conceito de competência comunicativa, foi destacada por Hymes (1971), a de viabilidade, a qual está associada a fenômenos sensoriais e cognitivos. No entanto, Bortoni-Ricardo (2004), prefere associar essa dimensão à noção de recursos comunicativos, tais como recursos gramaticais, de vocabulário, de estratégias retórico-discursivas etc., necessários para viabilizar um ato de fala. De acordo com esta concepção, as pessoas vão adquirindo recursos comunicativos à medida que vão ampliando suas experiências na comunidade onde vivem e passam a assumir diferentes papéis sociais. Ou seja, quanto mais tarefas comunicativas diferentes um falante experiencia mais recursos comunicativos esse falante dispõe em seu repertório lingüístico.

Neste contexto, a escola tem papel decisivo na aquisição desses recursos, pois tem o dever de proporcionar às crianças a realização de tarefas comunicativas complexas, que lhes permitam utilizar recursos comunicativos próprios para a escrita e para usar a língua oral, em estilos monitorados. A autora supracitada, destaca que quando tratamos de recursos comunicativos precisamos considerar três parâmetros associados à questão da ampliação desses recursos, que são: o grau de dependência contextual, o grau de complexidade do tema e a familiaridade com a tarefa comunicativa. (BORTONIRICARDO, 2005). Ao interagir com um interlocutor, o falante precisa levar em conta estes parâmetros para desempenhar bem as tarefas comunicativas nos contextos sociais em que interage. Não é difícil perceber, por exemplo, que quanto menor a dependência contextual, mais explícitos devem ser os enunciados e os falantes precisam utilizar vocabulário específico, sequenciadores e operadores lógicos, para que seu discurso seja mais claro e objetivo.

Dessa forma, também podemos exemplificar o segundo parâmetro em que diferentes graus de complexidade cognitiva podem ser exigidos de um falante dependendo da tarefa comunicativa que lhe é proposta. Se na escola, os alunos sempre lêem para a professora as respostas das atividades do livro-didático, eles já têm 


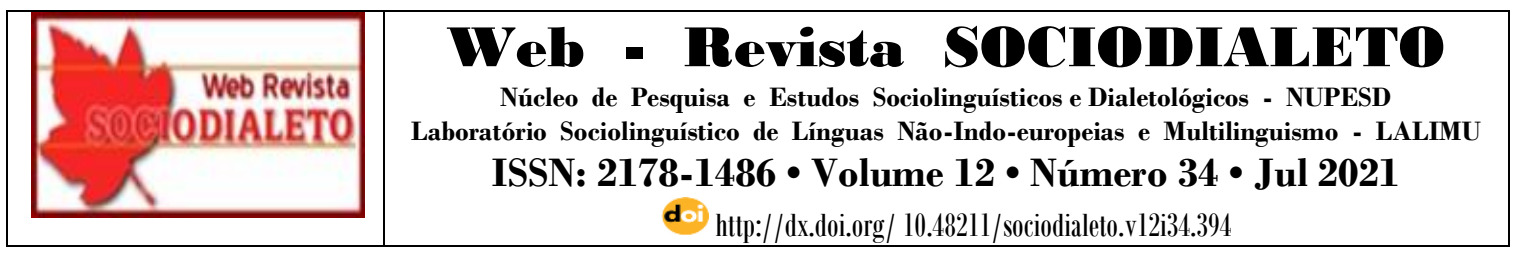

familiaridade com essa atividade (terceiro parâmetro), portanto para realizá-la não lhes é exigido um alto grau de complexidade. Todavia, se a professora propõe que além de lerem suas respostas os alunos deverão comentar com suas palavras o que leram, ela está proporcionando uma nova tarefa comunicativa que exigirá inicialmente um grau de complexidade cognitiva maior que o da tarefa anterior, mas que futuramente também será familiar e eles passarão a realizá-la sem muito esforço cognitivo.

A partir desses estudos sobre o conceito de competência comunicativa, BortoniRicardo (2005), assegura que as condições de apoio contextual, complexidade cognitiva e familiaridade com as rotinas comunicativas, já explicitadas neste capítulo, parecem influenciar de forma decisiva a viabilidade lingüística, parâmetro que envolve performance e aceitabilidade. Favorecendo a existência de uma diferença fundamental entre o que o falante não diz algo por não ter ocasião para dizê-lo e o que o falante não diz porque não possui os recursos lingüísticos, tais como vocabulário ou padrões retóricos específicos para dize-lo. Ou seja, sem esses recursos seu ato de fala não acontece, tornase inviável.

Nessa perspectiva, entendemos que a competência comunicativa e o seu desenvolvimento fazem parte do processo de aprendizagem pelo qual passam os indivíduos. Assim, tanto a família como a sociedade, inclusive a escola, são responsáveis por essa aprendizagem, pois ela vai acontecendo ao tempo em que o indivíduo vai se socializando.

Nesse contexto, as estratégias utilizadas pelo professor no processo interacional em sala de aula podem contribuir significativamente para criar um clima, no qual os alunos se sentem seguros para se expressarem. Assim, ao adotar a proposta de uma pedagogia culturalmente sensível, Cazden (1988) ao estudar as dimensões de continuidade e descontinuidade entre o lar e a escola na vida das crianças, especialmente em relação aos processos interacionais em sala de aula, divulgou o conceito de andaimes, assim definido por Bortoni-Ricardo (2008):

É um termo metafórico que se refere à assistência visível ou audível que um membro mais experiente de uma cultura presta a um aprendiz, 


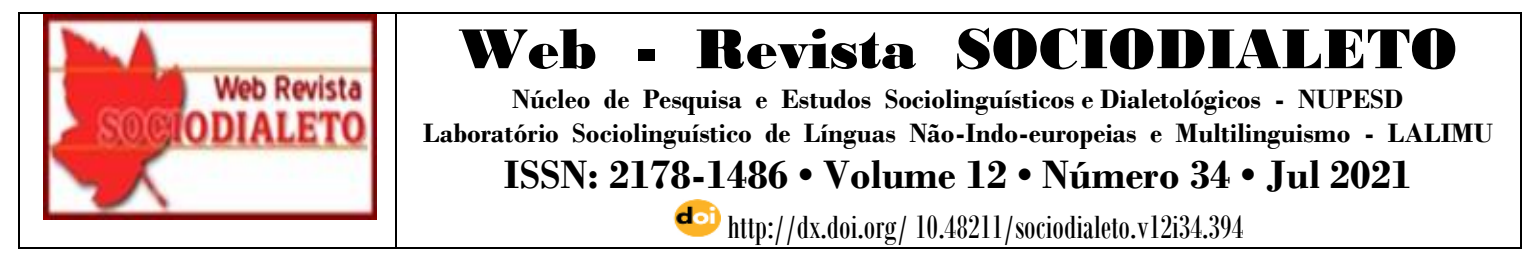

em qualquer ambiente social, ainda que o termo seja mais empregado no âmbito do discurso de sala de aula. (BORTONI-RICARDO, 2008, p. 44).

Ou seja, andaime ou scaffolding é o termo utilizado para designar o auxílio que, numa dupla, o parceiro mais competente pode dar ao outro. Podem ser consideradas como andaime estratégias que possibilitem ao aluno reelaborar seu pensamento original, tanto na dimensão cognitiva, quanto na dimensão formal, Tais como: a introdução que o professor faz ao lançar uma pergunta para a turma, a sobreposição da fala do professor à do aluno, os sinais de retorno, comentários, reformulações, reelaboração e paráfrase, expansão do turno de fala dos alunos etc. (BORTONI-RICARDO e SOUSA, 2006).

Algumas pesquisas realizadas no Brasil, como a de Oliveira (1995), revelaram o andaime como uma estratégia positiva empregada na sala de aula. Estratégias como essas favorecem ao predomínio de uma atmosfera de confiança e amizade na sala de aula e podem contribuir para o desenvolvimento da competência comunicativa do aluno e de sua consciência crítica das diferenças lingüísticas.

\section{PROCEDIMENTOS METODOLÓGICOS}

A natureza de nosso objeto de estudo, cujo propósito é investigar a relação que se estabelece entre a prática pedagógica do professor de língua portuguesa e a ampliação da competência comunicativa dos alunos dentro e fora do contexto escolar, torna evidente seu direcionamento para uma pesquisa sociolinguística de natureza qualitativa do tipo etnográfica.

A pesquisa qualitativa de acordo com Bortoni-Ricardo (2008) busca entender, interpretar fenômenos sociais inseridos em um contexto. Para a autora, a escola, e especialmente o microcosmo da sala de aula, é espaço privilegiado para a condução desse tipo de pesquisa. Acreditamos que pesquisas que se voltem para a interpretação dos fatos cotidianos que acontecem no interior da sala de aula e na comunidade podem ajudar a compreender melhor as ações de professores e alunos no processo interacional, bem como o processo de ensino e de aprendizagem. 


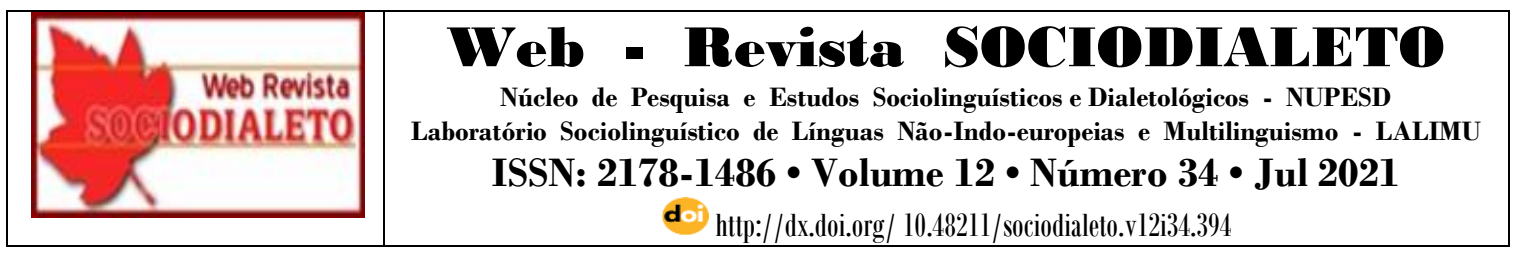

Entendemos ainda, que os problemas identificados em sala de aula podem estar relacionados à aspectos de natureza social, política e cultural da comunidade, por isso a importância de abordarmos nesta pesquisa, em uma perspectiva macrossocial, o bairro onde a escola está inserida. Além do que as informações de nível macro nos ajudam a conhecer melhor os sujeitos envolvidos.

O método de investigação escolhido para a realização desse estudo, etnografia, permite a escuta do outro, ou seja, ver como o outro vê, sentir como o outro sente, como afirma Maffesoli (1985). A palavra etnografia que literalmente significa "escrever sobre o outro" (ERICKSON, 1988) é composta de dois radicais do grego: ethnoi, que significa "os outros", ou seja, se refere a grupo de pessoas que não são gregos e graphos que significa "escrita". O termo foi criado por antropólogos no final do século XIX para se referirem a monografias que vinham sendo escritas sobre os modos de vida dos povos não ocidentais, como a monografia de Malinowski (1922) sobre os habitantes das ilhas Kiriwina, situadas na Papua Nova Guiné, no Oceano Pacífico (BORTONI-RICARDO, 2008).

Segundo Lima (1996), a etnografia como abordagem teórico-metodológica dos fatos sociolinguísticos, tem contribuído significativamente para pesquisas no campo sócioeducacional. De origem antropológica, ela se constitui atualmente em uma metodologia que se volta preferencialmente para os processos do dia-a-dia em suas diversas modalidades, isto é, para os fatos reais da vida cotidiana (LIMA, 1996). Erickson (1988, p. 81) define que “[...] os objetivos centrais da descrição etnográfica na pesquisa sociolinguística são documentar e analisar aspectos específicos das práticas de fala, da maneira como se situam na sociedade em que ocorrem." Daí compreendemos que tais objetivos incluem os de pesquisas como a nossa que pretendem responder a questões educacionais, observando os sujeitos, os espaços e contextos sócioculturais onde a interação se processa.

Bortoni-Ricardo (2008) também delimita que o objetivo da pesquisa qualitativa em sala de aula, especialmente da etnografia, “[...] é o desvelamento do que está dentro da "caixa preta" no dia a dia dos ambientes escolares, identificando processos que, por serem rotineiros, tornam-se "invisíveis" para os atores que deles participam [...]" 


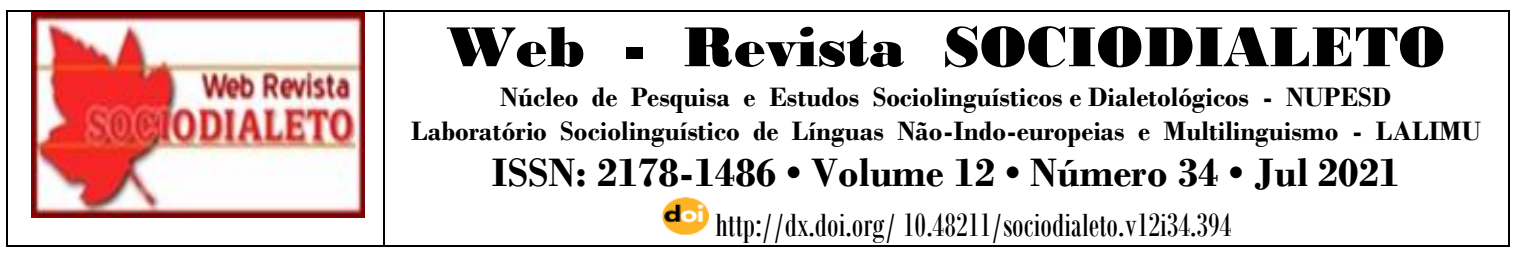

(BORTONI-RICARDO, 2008, p. 49). Assim, através da etnografia, podemos chegar a uma descrição das ações praticadas num dado espaço, num dado momento e, especificamente neste trabalho, à descrição do que acontece na sala de aula da forma mais real possível. Ou seja, das atitudes e da postura do professor de língua materna frente às manifestações orais dos alunos, às atividades propostas em sala de aula que possam contribuir para o desenvolvimento das habilidades de expressão oral e escrita dos alunos e o significado destas ações para o professor e para os alunos.

Enfim, o que pretendemos por meio da etnografia é: "tornar o familiar estranho, é problematizar o que parece comum, é tornar visíveis e explícitas ações não percebidas rotineiramente, exatamente por serem consideradas óbvias" (CAJAL, 2001, p. 134). A partir dessas considerações, investigaremos nosso objeto de estudo, segundo uma das abordagens da pesquisa sociolinguística denominada etnografia da comunicação.

Como afirma Saville-Troike (1982), fazer etnografia, em qualquer contexto cultural, envolve, a princípio, observação, questionamentos e participação nas atividades cotidianas. Assim, adotamos a técnica de observação participante, convivendo e a observando o processo comunicativo que ocorre no interior da sala de aula. Para tanto, utilizamos gravações em áudio e vídeo dos eventos de sala de aula e das entrevistas, além, do registro escrito no diário de campo. Os eventos de sala de aula foram descritos e analisados com base no trabalho de Lima (1996), cujos eventos são descritos mediante um esquema formal adaptado de Saville-Troike (1982), a considerar as seguintes aberturas:

1)Evento: é a descrição da atividade de interação social entre os participantes.

2)Propósito: é a descrição da finalidade da atividade de interação social.

3)Participantes: descreve os participantes envolvidos na atividade de interação social.

4)Formas de mensagem: apresenta os tipos de linguagem que guiam a interação social.

5)Regras de interação: descreve os acontecimentos decorrentes da atividade.

Nos eventos de sala de aula, analisamos a fala da professora nas seguintes situações: discussão de um determinado tema ou conteúdo, respostas após às perguntas dos alunos, comentários após as respostas ou opiniões dos alunos, correções que faz 


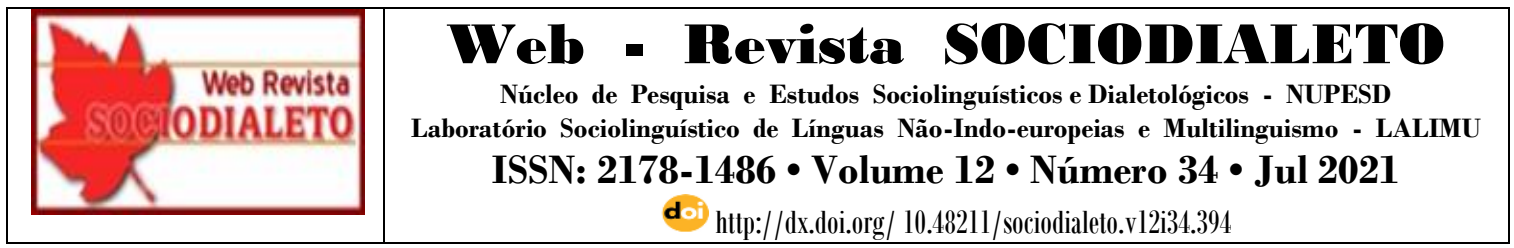

relacionadas às falas dos alunos, propostas de atividades a serem realizadas pelos alunos; e a fala dos alunos nas situações: leituras, respostas, interpretações, comentários e exposições em sala de aula. Procuramos identificar nestas situações, marcas que demonstrassem que a prática pedagógica da professora pode propiciar a ampliação da competência comunicativa dos alunos. Em seguida, descrevemos o cenário da investigação, os sujeitos e os procedimentos de coleta e análise dos dados.

\subsection{Instrumentos de coleta de dados}

Utilizamos como instrumentos para a produção dos dados, a observação participante, a entrevista informal, gravações em áudio e anotações em diário de campo. A observação participante é considerada uma das técnicas mais utilizados para a coleta de dados em estudos que adotam uma abordagem etnográfica. Bailey (1968) explicita que a observação participante tem a vantagem de possibilitar ao pesquisador um registro do comportamento dos participantes no próprio jogo interacional, o que lhe proporciona a oportunidade de estabelecer uma relação íntima com os observados.

Durante a coleta de dados a observação participante foi uma das técnicas que contribuiu significativamente para o desenvolvimento da pesquisa, pois possibilitou a aproximação direta do pesquisador com a realidade a ser pesquisada. Nesse tipo de instrumento de coleta de dados a observação de fatos, ações e cenários precisa ser valorizada. Nesse sentido, concordamos com Freitas et. al (2003, p. 61) sobre a importância de "saber escutar/ouvir e observar/ver e considerar tanto a racionalidade como a sensibilidade, a fim de compreender a história e os acontecimentos" que fazem parte deste contexto investigativo.

Através da observação participante tentamos entender os eventos e as pessoas, adotando os papéis e perspectivas daqueles que investigamos (ERICKSON, 1988). Como afirma Saville-Troike (1982) fazer etnografia em qualquer contexto cultural, envolve, em princípio, observação, questionamentos e participação nas atividades cotidianas. Assim, adotamos a técnica de observação participante, passando a conviver, a participar e a observar o processo comunicativo que ocorre no interior da sala de aula, a fim de 


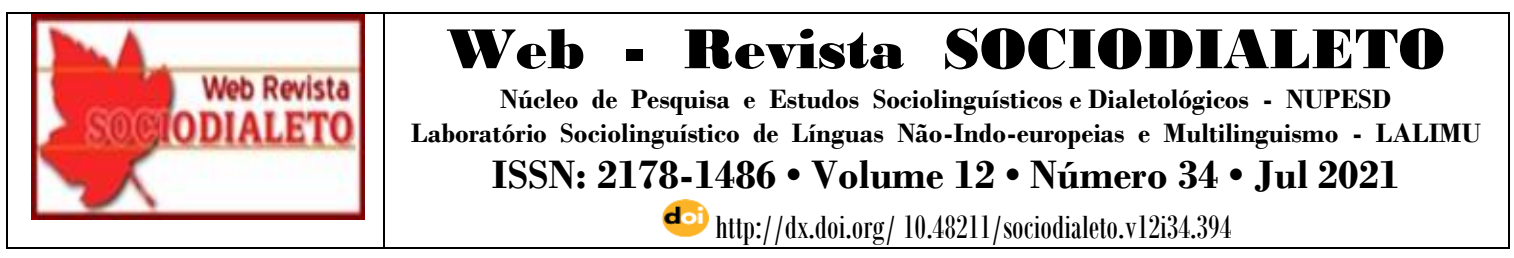

caracterizar a relação entre a prática pedagógica do professor e a ampliação da competência comunicativa, tendo em vista a natureza sociolinguística deste estudo. Para tanto, utilizamos gravações em áudio dos episódios de sala de aula e das entrevistas, além do registro escrito no diário de campo.

Nos eventos de sala de aula, gravamos a fala dos professores nas seguintes situações: discussão de um determinado tema ou conteúdo, respostas após às perguntas dos alunos, comentários após as respostas ou opiniões dos alunos, correções que fazem relacionadas às falas dos alunos, propostas de atividades a serem realizadas que privilegiem os gêneros orais. Lüdke e André (1986) alertam quanto a alguns problemas que precisam ser considerados pelo pesquisador nesse procedimento de coleta de dados. Um deles refere-se às alterações que podem aparecer como modificações no ambiente ou no comportamento das pessoas observadas; outro está ligado aos cuidados na hora da interpretação dos dados; outro ainda, está relacionado com o grande envolvimento do pesquisador, podendo levar a uma visão distorcida ou parcial da realidade. A fim de não correr esse risco a nossa identidade e os nossos objetivos foram esclarecidos para os observados, os quais estavam conscientes de que a nossa relação era de observador e observados.

Isso foi relevante para que pudéssemos manter uma certa distância do grupo e observá-lo sem interferir no seu comportamento natural mesmo fazendo parte de sua rotina e de suas atividades diárias. Utilizamos um gravador digital para registrar as situações de interações estabelecidas com os sujeitos, isto é, as aulas observadas e as entrevistas realizadas, pois esse procedimento permite uma revisitação constante dos eventos registrados e fornece precisão na descrição de detalhes importantes (ERICKSON, 1988).

Segundo Bortoni-Ricardo (2008), a gravação eletrônica em vídeo ou áudio é de grande vantagem na coleta de dados porque permite ao pesquisador rever os dados repetidas vezes podendo tirar suas dúvidas e apurar a teoria que está construindo. Nossas observações se realizaram de forma tranquila e com a colaboração direta dos sujeitos envolvidos. 


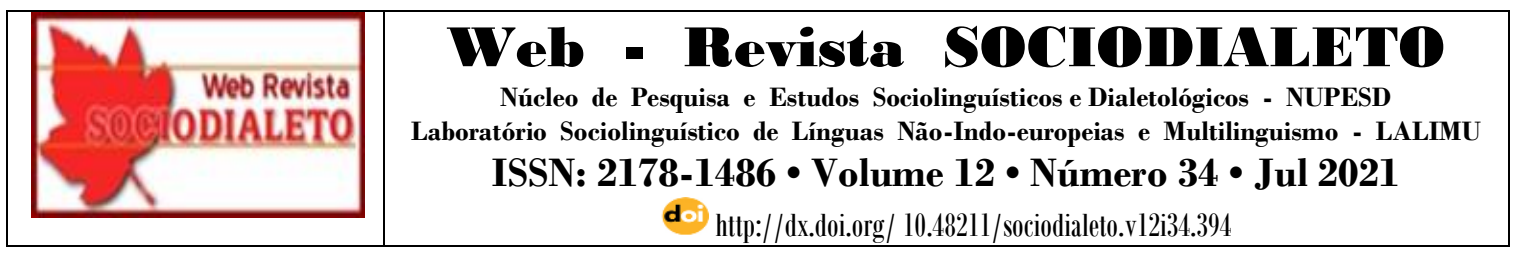

Considerando os objetivos propostos neste estudo, uma técnica de coleta de informações bastante utilizada foi a entrevista informal, enquanto forma de interação entre pesquisador e pesquisado, em que "o pesquisador visa apreender o que os sujeitos pensam, sabem, representam, fazem e argumentam”. (SEVERINO, 2007, p. 124). No decorrer dessas entrevistas procuramos praticar um diálogo descontraído, deixando os interlocutores à vontade para expressar suas representações sem constrangimentos, intervindo discretamente para estimulá-los. Para registrar as informações, utilizamos um gravador digital e um diário de campo.

As entrevistas informais realizadas com os professores de língua portuguesa do $6^{\circ}$ ano ocorreram na própria escola, após o término das observações e depois do horário de aula. Tais entrevistas nos ajudaram a identificar as concepções linguísticas desses professores subjacentes às atividades desenvolvidas em sala de aula para posteriormente avaliarmos confrontando as informações aqui obtidas com as da observação participante, se há coerência entre o que se diz e o que se faz. De acordo com Minayo (1994):

A entrevista é o instrumento mais usual no trabalho de campo. Através dela, o pesquisador busca obter informes contidos na fala dos atores sociais. Ela não significa uma conversa despretensiosa e neutra, uma vez que se insere como meio de coleta dos fatos relatados pelos autores enquanto sujeitos-objeto da pesquisa que vivenciam uma determinada realidade que está sendo focalizada. (MINAYO, 1994, p. 57).

Devido a sua natureza interativa, a entrevista informal possibilita uma exploração mais aprofundada de temas complexos que possivelmente poderiam ser tratados por meio de questionários. No entanto, não deixariam transparecer detalhes importantes para uma análise etnográfica. Além disso, a entrevista permite clima interativo de influência recíproca entre pesquisador e pesquisado.

\subsection{Procedimento para análise dos dados}

Os procedimentos para análise dos dados foram a escuta e leitura atenta e cuidadosa do material coletado, o que nos possibilitou uma análise criteriosa e embasada 


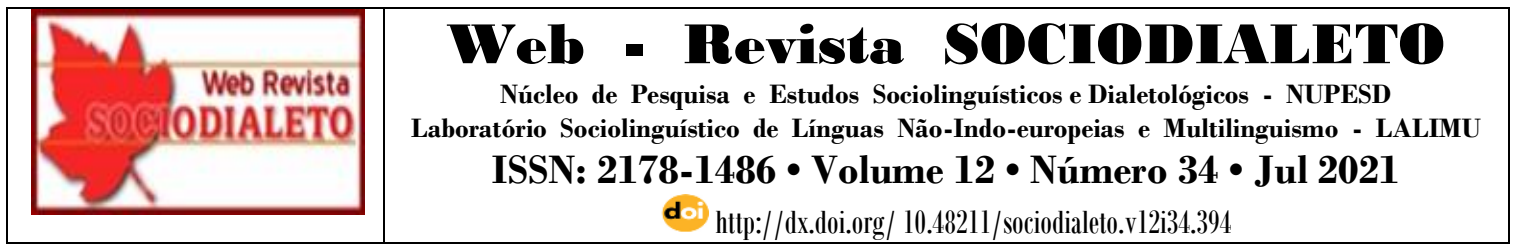

nas falas de nossa interlocutora e na leitura selecionada. As análises partiram de estudos da literatura sobre o que deve ser feito para desenvolver a competência comunicativa dos alunos, como as crenças, a postura, as atitudes e as estratégias desenvolvidas pelo professor em sala de aula podem contribuir para esse desenvolvimento, do contato com a realidade da escola e da comunidade e do diálogo com a diversidade dos dados obtidos.

Em nossas análises privilegiamos também os estudos de Dell Hymes (1972b), que contribuíram para a fundamentação dos padrões de interação em sala de aula e a observação do desenvolvimento da competência do aluno a partir de suas reflexões. Além disso, aproveitamos em nossa pesquisa o conceito de pedagogia culturalmente sensível, de Erickson (1987), com a finalidade de sustentar a discussão sobre a importância do processo pedagógico.

Ressaltamos que a análise dos dados obtidos através dos diferentes registros (observação participante, diários de campo, fotos, gravações de áudio e entrevistas) tem sido viabilizada através da triangulação, que é uma comparação de evidências através de fontes de dados diferentes. Assim, a triangulação "fornece uma verificação de validade, sendo uma das principais razões da pesquisa etnográfica empregar métodos múltiplos de coleta de dados." (ERICKSON, 1988, p. 97).

Segundo Bortoni-Ricardo (2008), a triangulação é um recurso analítico que viabiliza a comparação de dados de diferentes tipos para que uma asserção seja confirmada ou desconfirmada, bem como permite a comparação das perspectivas dos diferentes interlocutores em ação. Assim, os dados coletados são oriundos de diferentes fontes: das observações em sala de aula, das entrevistas informais, das gravações dos eventos de aula, bem como das anotações em diários de campo.

Para concluir, evidenciamos que a utilização desse recurso tem nos possibilitado a análise dos diferentes dados e a validação das informações obtidas. Além do que, a comparação entre as concordâncias ou discrepâncias nas diferentes perspectivas dos interlocutores nos permite compreender as crenças, as atitudes, as concepções e os significados atribuídos pelos sujeitos investigados.

\subsection{A escola e os sujeitos}


A escolha da escola se justifica por ser uma instituição pública que apesar de enfrentar as dificuldades que qualquer escola pública enfrenta, seus alunos têm apresentado bons resultados nos exames realizados pelo Sistema de Avaliação da Educação Básica (SAEB) e vêm sempre se destacando dentre as escolas públicas do estado do Piauí.

Além disso, também consideramos como critério para a escolha, o fato de mantermos relações amigáveis com professores e supervisores da escola. Esperamos que uma análise sobre esta realidade nos permita refletir sobre o ensino de língua portuguesa e as interações que se realizam no espaço da sala de aula.

O espaço onde a escola fica situada é bem amplo e ladeado por árvores bem desenvolvidas que deixam o local bastante sombreado. A escola possui uma quadra cimentada e coberta mais ao fundo do terreno e ao lado da quadra uma igrejinha. A construção se divide em dois blocos separados pelo amplo espaço sombreado: o primeiro bloco é uma construção mais recente que comporta uma sala de professores com banheiro, quatro salas de aula no térreo e banheiros; um laboratório de informática, quatro salas de aula, um banheiro masculino e um feminino no $1^{\mathrm{o}}$ andar; o outro bloco, mais antigo, também conta com sala de professores, biblioteca, coordenação, secretaria, cozinha, dois banheiros para os alunos maiores e dois para os menores, dezessete salas de aula e um local reservado aos dormitórios e refeitórios das freiras que dirigem a escola.

A professora já leciona há mais de 20 (vinte) anos na escola e desde muitos desses anos trabalha com $4^{\circ}, 5^{\circ}$ e $6^{\circ}$ anos, ou seja, acompanha os alunos nestas séries. A professora é licenciada em Letras - Português e cursa especialização em Psicopedagogia.

Em sala de aula, a professora dirige as ações, promovendo a participação dos alunos nos turnos de fala, e de vez em quando lembrando as regras educacionais básicas de participação, tais como: levantar a mão antes de falar, esperar a vez de falar, ouvir com atenção o colega, etc. Preocupa-se muito com a formação moral e religiosa das crianças, sempre inicia suas aulas com a leitura e discussão de um texto bíblico. Durante as explicações situa-se principalmente em pé em frente às carteiras das crianças, e quando propõe atividades anda pelas fileiras oferecendo ajuda e observando como os alunos estão 


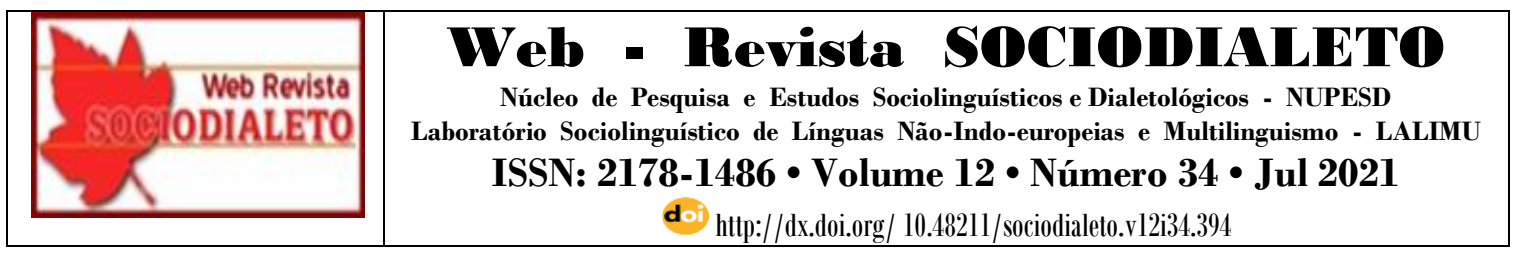

realizando a atividade proposta. Em entrevista informal, a professora diz que se sente realizada profissionalmente, pois adora trabalhar com crianças e que várias vezes já lhe ofereceram a oportunidade de exercer outras funções na educação, no entanto ela prefere a sala de aula, segundo depoimento a seguir:

Eu já completei 22 anos né de profissão, e, assim... é uma coisa que eu faço por amor, eu gosto, eu gosto de trabalhar, eu tenho um ano e meio de licença e eu não sinto vontade de tirar, às vezes assim... eu tenho vontade, mas eu me sinto bem aqui na escola, na escola que eu trabalho que faz essa quantidade de tempo né, eu já recebi alguns convites pra exercer uma outra função, mas eu não aceitei porque eu não me identifico. Hoje quando eu cheguei aqui e vi ali o resultado do IDEB, assim eu ganhei meu dia... (PROFESSORA DO $6^{\circ}$ ANO).

Em conversas informais com os alunos, na hora do recreio, sentimos que há uma relação afetiva muito forte entre eles e a professora, pois falavam dela demonstrando muito carinho. A coordenação e as outras professoras da escola também avaliaram de forma bastante positiva o trabalho da professora e a forma com que lidava com os alunos, conforme pudemos perceber no relato da coordenadora a seguir: [...] "ela é uma ótima educadora, desenvolve os programas da escola bem direitinho, na aula dela os meninos não gritam, não bagunçam, eles participam com disciplina [...]”.

A sala de aula pesquisada conta com 30 (trinta) crianças, com idade média entre 10 e 11 anos. A origem social das crianças é bastante heterogênea, a escola recebe alunos da comunidade e alunos que se deslocam todos os dias de cidades menores ou de zona rural. Os pais exercem as mais diferentes funções: professores, domésticas, bombeiros, pedreiros, comerciantes etc.

A seguir descreveremos um evento de aula de língua portuguesa do $6^{\circ}$ ano da Escola, com o objetivo de analisar, através das tarefas comunicativas da professora e dos alunos, as estratégias desenvolvidas em sala de aula que favorecem a ampliação da competência comunicativa dos alunos. Nesse evento, a professora através da leitura e interpretação oral e escrita de um texto do gênero "carta de solicitação", ao tempo em que proporciona o conhecimento das características de um gênero textual vai possibilitando o 


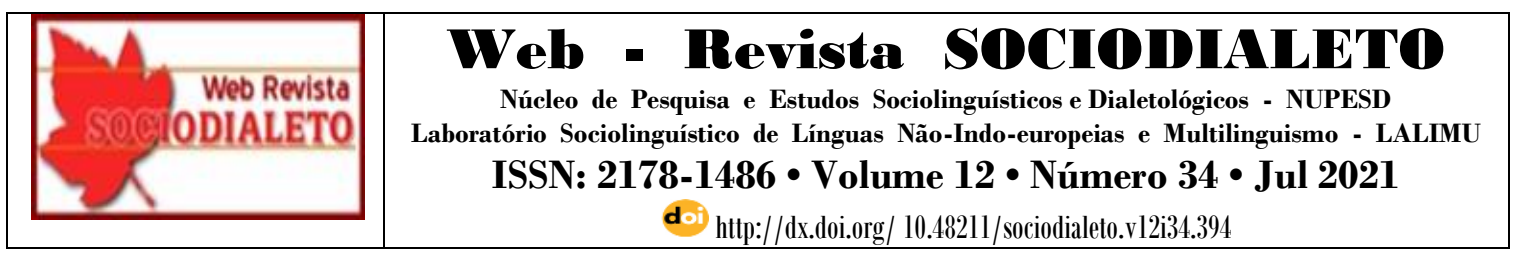

conhecimento de quando é adequado falar ou não, sobre o que falar e com quem, quando, onde e como, ou seja, enriquecendo as experiências comunicativas dos alunos, como uma das formas de favorecer a ampliação da competência comunicativa de que fala BortoniRicardo (2005).

Entre as estratégias positivas observadas nessa sala destacamos a concessão da palavra aos alunos, pois a professora implementa estratégias de envolvimento, permitindo que os alunos falem, ratificando-os como falantes legítimos e incentiva-os a manifestarse. Podemos dizer que esta estratégia faz parte do que vem sendo reconhecido pelos estudiosos como scaffoolding, ou "andaimagem", termo utilizado por Cazden (1988) que significa a ajuda que, numa dupla, o parceiro mais competente, pode dar ao outro, esse parceiro mais competente pode ser o próprio professor ou o próprio aluno. As ações de scaffolding podem contribuir para o desenvolvimento da competência comunicativa do aluno e de sua consciência crítica das diferenças lingüísticas.

Tais estratégias têm favorecido ao predomínio de uma atmosfera de confiança e amizade na sala de aula. Outra estratégia positiva é que ela fornece modelos de estilos monitorados de língua e mostra quando e como usar esses estilos.

O evento consiste em exposições acerca de um texto do gênero "carta de solicitação", onde se estabelecem diálogos entre professores e alunos, em que a tomada de piso pelos alunos não é totalmente livre, pois é geralmente introduzida por um vocativo ("professora", "tia") ou pelo levantar de braço e provocada por uma pergunta da professora. O que demonstra também que os alunos já adquiriram regras de interação de sala de aula. O tema da interação do evento descrito atém-se a um conteúdo informacional que o professor quer transmitir e não ao contexto situacional imediato.

Faz-se relevante destacar que o modelo de evento de fala utilizado segue o descrito no trabalho de Lima (1996), construído a partir de Saville Troike (1982).

\section{AULA DE LÍNGUA PORTUGUESA: UMA ANÁLISE ETNOGRÁFICA}

Evento: Aula de ensino de Língua Portuguesa ( $6^{\circ}$ ano, Ensino Fundamental)

Propósito: Desenvolver atividades de leitura e interpretação de texto. 


\begin{tabular}{|c|c|}
\hline $\begin{array}{l}\text { Web } \\
\text { ODIA }\end{array}$ & 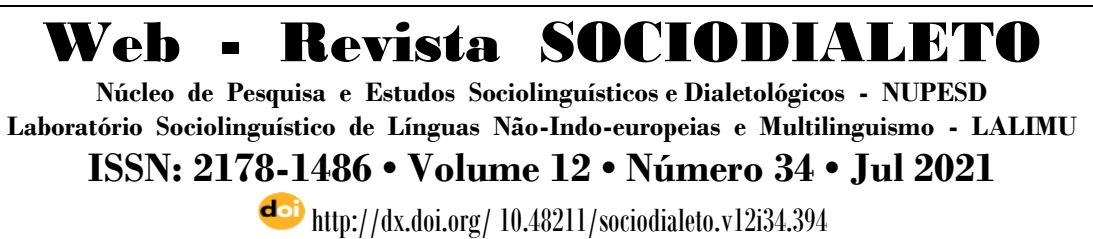 \\
\hline
\end{tabular}

Participantes: Professora, alunos na faixa etária de 10 a 12 anos.

Regras de interação: $O$ professor solicita constantemente a participação dos alunos através de perguntas sobre as características do gênero em questão e estes podem tomar o piso a qualquer momento.

A sala onde ocorre a aula está organizada de forma tradicional. Na frente o quadro de acrílico e a mesa da professora, numa posição de onde visualiza toda a sala. Na outra parte, de frente para a mesa estão as carteiras das crianças.

Professora e alunos participam interacionalmente da aula. A professora geralmente é quem dirige as atividades, mas permite que os alunos participem da aula independentemente de serem solicitados ou não.

As aulas sempre iniciam após a leitura e discussão de um texto bíblico e a chamada dos alunos é feita pelo nome para efeito de registro no diário de classe. Após esse evento a professora toma algumas medidas de ordem disciplinar.

Ao iniciar a aula a professora pede que os alunos coloquem sobre a mesa o texto que receberam na aula anterior:

P: Eu entreguei na aula anterior uma apostila, do que ela trata?

As: De uma carta

P: E com que finalidade a gente escreve uma carta?

A1: Como meio de comunicação...

A2: Notícia...

P: E quais são os componentes composicionais de uma carta?

Os alunos ficam em silêncio, parecem que não entenderam a pergunta, certamente pelo termo utilizado pela professora "componentes composicionais" que ainda não fazia parte do vocabulário deles. Destacamos o comentário de Bortoni-Ricardo (2005) ao tratar da viabilidade no conceito de competência comunicativa, segundo a autora um ato de fala pode se tornar inviável para o falante se este não tiver acesso aos recursos linguísticos necessários para a implementação desse ato de fala, como por exemplo, vocabulário. Hymes (1974a), afirma que há uma diferença fundamental entre o que não é dito porque não há ocasião para dizê-lo e o que não é dito porque o falante não dispõe de meios para 


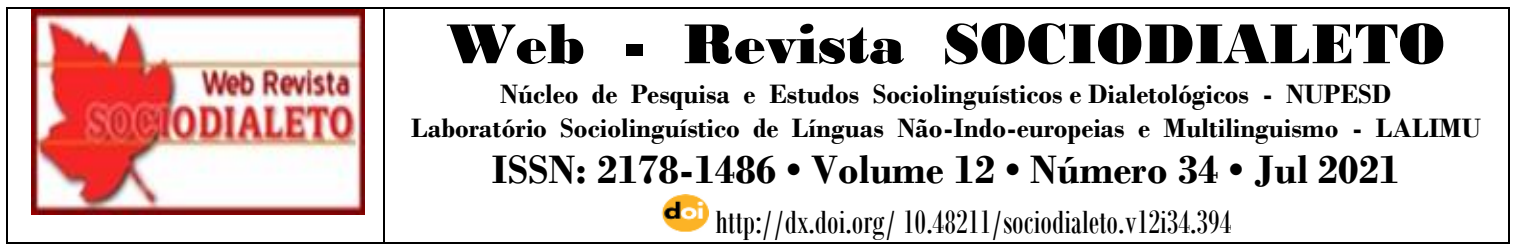

dizê-lo. Assim, um falante exibirá maior competência comunicativa, quando dispõe de recursos formais, apropriados e específicos, para realizá-los e quando participa de eventos de fala que lhes são familiares. Observamos que a professora ao perceber que não compreenderam refaz a pergunta, substituindo a expressão (construção composicional) não compreendida pelos alunos. E, somente quando percebe que compreenderam o que ela estava perguntando volta a utilizar o termo "construção composicional" novamente no curso da interação, possibilitando a ampliação do vocabulário de forma natural. Proporcionando aos alunos melhor entendimento sobre o tópico que rege essa interação, a "viabilidade" de uma comunicação eficiente é ampliada, pois os interactantes estão adquirindo recursos lingüísticos específicos e apropriados sobre aquele tópico. Assim a professora substitui a pergunta: "P: Como inicia a carta, pessoal? As: Com o local e a data".

A professora anota no quadro: local e data, saudação, desenvolvimento, ela explica que é o próprio corpo da carta, despedida e assinatura. Explica que estes são os componentes composicionais deste gênero. Em seguida pede que todos os alunos leiam o texto juntos. Ela lê junto, procurando fazer com que os alunos a acompanhem na entonação de voz, ritmo, pontuação e pronúncia.

P: Para quem a carta foi escrita? quem é o destinatário?

As: A Sra Dora Nogueira

P: Qual a função social da $\mathrm{Sr}^{\mathrm{a}}$ Dora Nogueira? Que atividade ela exerce?

A1: Secretária de Educação do Município.

A professora queria que eles soubessem que destinatário e a pessoa que vai receber a carta são a mesma coisa, então ela refaz a mesma pergunta de forma diferente, antes que eles respondam. Essa estratégia se repete também quando pergunta qual é a função social do destinatário. Ao fazer isso, ela procura fazer com que os alunos usem o que já sabem de modo a conferir significado ao que lhes apresenta e possam estar relacionando o novo conhecimento ao antigo, ou seja, nesse momento ela está optando por ativar o conhecimento prévio dos alunos. Após a resposta da aluna ela enfatiza: 
P: muito bem! É importante a gente saber que atividade exerce a pessoa a quem a carta é dirigida, porque neste tipo de carta o motivo pelo qual ela foi escrita, que é um pedido, tem uma relação com a função que exerce essa pessoa. Agora observem: no $1^{\circ}$ parágrafo da carta tem a finalidade na qual ela foi elaborada. Qual é? Leiam e me digam.

Nesse momento ela leva os alunos a perceberem a importância da relação entre o que está sendo dito, ou seja, o assunto que está sendo abordado e a pessoa a quem é dirigida a mensagem. A professora vai possibilitando a ampliação do conhecimento sobre o que é adequado falar e com quem. "P: Quem está solicitando? As: Os professores"

Nesse momento ela explica aos alunos porque a carta foi escrita em $1^{a}$ pessoa do plural (nós), pois apesar de ter sido escrita pela Presidente do Sindicato dos Professores representa uma classe.

\author{
P: O que eles estão pedindo? \\ A3: horas de trabalho pedagógico. \\ P: Muito bem A3, para que? \\ A4: Pra reforçar o desempenho de alguns alunos.
}

Aqui a professora elogia a fala do aluno e acolhe a sua resposta aproveitando-a para elaborar outra pergunta para turma, fazendo com que ele sinta que o que ele falou foi importante para a continuidade da interação que está sendo promovida, incentivando o aluno a manifestar-se. Com isso ela consegue obter a participação de outra criança. Além disso, percebemos na resposta da aluna A4 a utilização de palavras do texto (reforçar, desempenho) adequadas perfeitamente em sua fala, o que demonstra que em eventos de letramento permeado pela oralidade os alunos estão adquirindo um estilo monitorado, como afirma Bortoni Ricardo e Dettoni (2001, p. 98, 99): “à medida que os alunos desenvolvem hábitos lingüísticos para a prática de eventos de letramento, poderão transferi-los para eventos de oralidade que, estando próximos do pólo do letramento, exigem planejamento e, por conseguinte, monitoramento". 


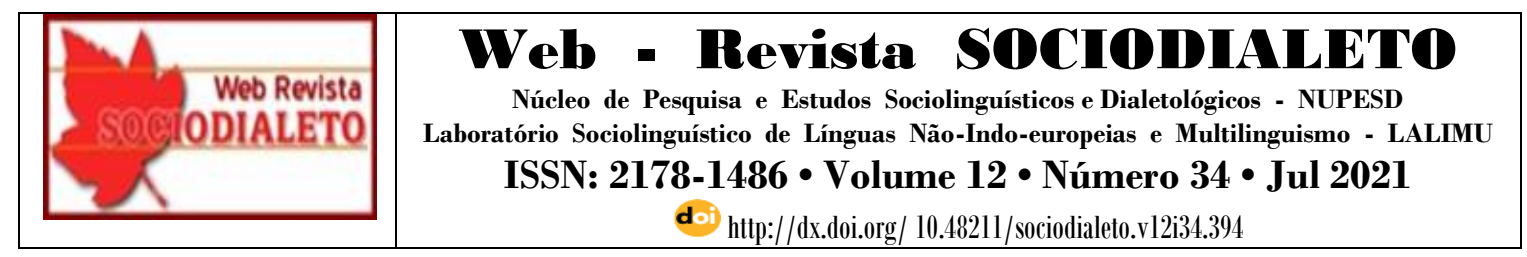

P: Neste pedido eles usaram o nome de uma pessoa competente pra reforçar pra secretária a importância deste horário. Quem é essa pessoa?

A4: Um pedagogo, Antônio Nóvoa.

P: Ela usou o nome de um pedagogo que é uma pessoa que estuda, um profissional que entende de educação, tem conhecimento da importância desse horário, usou esse nome para reforçar. Por exemplo, a gente diz assim: "olha eu fui pra procissão de Santo Antônio, até a irmã tava lá”, por que a gente usa o nome dela? Porque é uma pessoa que tem respaldo na nossa comunidade.

Interessante como a professora demonstra que em eventos de oralidade, as pessoas utilizam o respaldo que outras pessoas da comunidade têm, isto é, a credibilidade que elas possuem junto à sociedade para abordar determinado assunto. A professora coloca uma outra situação para que os alunos percebam, em um outro contexto específico, que é comum usarmos, inclusive em situações informais de oralidade, a voz de uma outra pessoa para respaldar o que estamos dizendo, no caso, a importância que tem a irmã (diretora da escola) ao participar de um evento religioso na cidade, que é a procissão de Santo Antônio. Ao longo desse evento, observamos que a professora exibe certo planejamento e monitoramento de sua linguagem. No entanto, fica claro que a professora usa, para dar exemplos aos alunos, um estilo mais informal, mais comum na linguagem coloquial no Brasil: “a gente diz assim”, “até a irmã tava lá”. Segundo Bortoni-Ricardo (2005), essa mudança de código que a professora realiza é positiva por duas razões, primeiro porque torna evidente para as crianças que existem formas diferentes de usar a língua e que quando participamos de um evento mais próximo do pólo da oralidade, cuja interação não é mediada pelo texto escrito, usamos a linguagem coloquial; e segundo, porque nos eventos de escrita e leitura, em suas diferentes manifestações a professora intuitivamente passa a monitorar sua linguagem, o que propicia às crianças o contato com a norma de prestígio da língua, à qual elas quase não têm acesso. Ao fornecer modelos em língua padrão, podemos dizer que a professora utiliza a estratégia positiva de "andaime". (CAZDEN, 1988).

A professora chama o A5 como forma de atrair sua atenção para participar da interação porque ele estava conversando com o colega da frente. "P: A5, leia o $3^{\circ}$ 


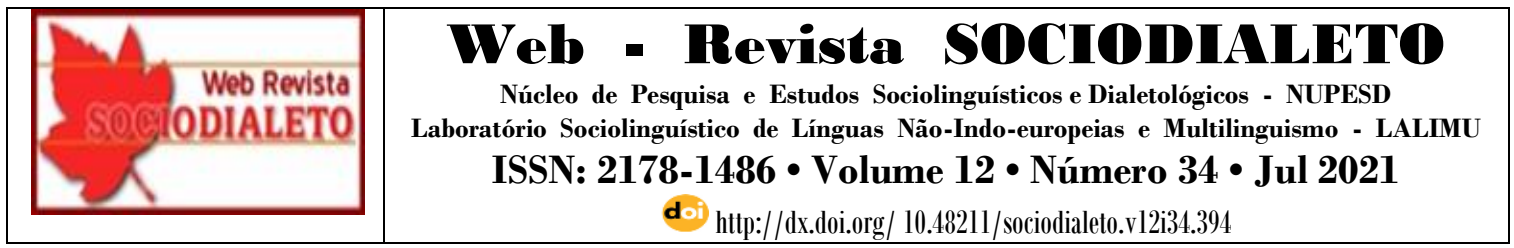

parágrafo da carta". Não só o A5 como também o colega começa a ler juntos. Ao terminarem a leitura ela pergunta:

P: O que entenderam?

A5: Tia, esse projeto é melhor fora do horário das aulas.

P: Muito bem, vocês compreenderam direitinho. Agora vamos continuar prestando atenção e participando, tá?

Nesse excerto, ela ratifica a fala do aluno com um reforço positivo verbal e não verbal, confirmando a resposta com a cabeça. Observe-se que a cena descreve um momento em que a professora avalia oralmente a compreensão de um texto lido pelos alunos. A ratificação plena da fala do aluno como ocorre aqui já foi observada também por Dettoni (1995) que identificou em eventos de interação em sala de aula três formas diferentes de ratificação: a ratificação plena da fala do aluno, que pode vir ou não acompanhada de reforço positivo verbalmente expresso pelo professor (a) ou de gestos com as mãos ou com a cabeça que confirmem essa fala; a ratificação parcial, que ocorre geralmente em correções de exercícios em que o aluno tem acesso ao piso, mas sua fala não é totalmente ratificada pelo professor (a) ou porque não é considerada totalmente apropriada para a ocasião ou porque a expectativa do professor (a) é maior; e por fim, a não-ratificação, casos em que várias tentativas de intervenção dos alunos podem não ser identificadas pelo professor (a). Segundo a autora esses tipos de ratificação estão relacionados ao estilo do professor, ela observou que "a professora com estilo flexível estava menos preocupada com as expectativas institucionais e ajustava-se mais facilmente às mudanças de tópico que surgiam durante a interação", enquanto a de estilo formal ratifica parcialmente ou não-ratifica a fala do aluno devido "ao não preenchimento das suas expectativas institucionais".

P: Então a escritora usa vários argumentos pra convencer a secretária da necessidade do reforço. E, ao final da carta ela também usou a sua função social, a de Presidente do Sindicato dos Professores. Apesar de assinar a carta, a solicitação não é só dela, da Jussara, é de toda a 


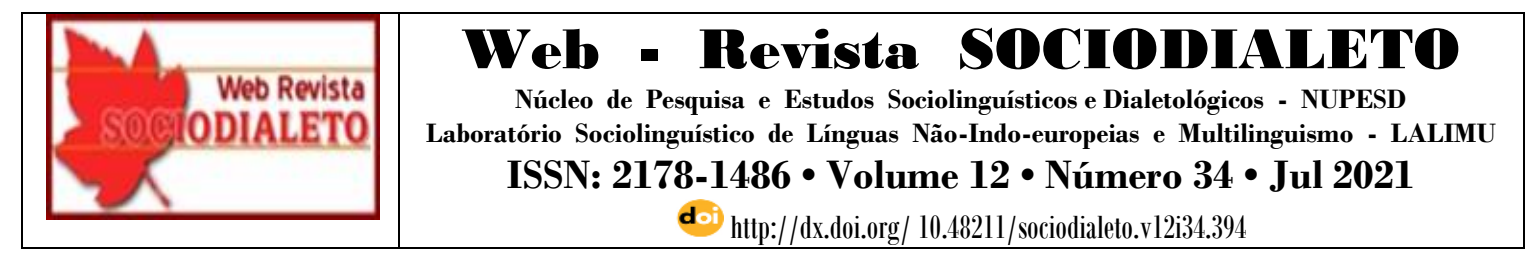

coletividade, de todos os professores. De que maneira o produtor do texto procura convencer o destinatário de que seu pedido é pertinente?

A6: (o aluno responde em voz baixa).

P: A6 fale mais alto, eu e seus colegas não estamos ouvindo.

A professora sempre usa a estratégia de repetição e recomendação para que os alunos falem ou leiam mais alto. Ela usa esse recurso para indicar que o estilo deve mudar, que o aluno vai assumir o piso e, em consequência, deve alterar seu estilo para um estilo mais monitorado, marcado pelo tom mais alto e por um maior grau de atenção e planejamento.

Através dessa breve análise percebemos que mesmo monitorando o ambiente de aprendizagem a professora consegue estabelecer um clima de confiança e liberdade e fazer com que os alunos participem das discussões mesmo quando não são solicitados. Dessa forma, a interação acontece por meio do exercício da linguagem possibilitando por meio da troca verbal, outras trocas como a afetiva e a intelectual (CAJAL, 2001).

\section{CONSIDERAÇÕES FINAIS}

Percebemos através das análises realizadas que as estratégias utilizadas pela professora são bastante positivas para desenvolver a competência comunicativa dos alunos, especialmente no que diz respeito à oralidade. Na sala de aula, prevalece um clima de confiança, pois há constantemente o acolhimento e a ratificação da fala dos alunos. A professora vai ampliando naturalmente o vocabulário dos alunos, como forma de possibilitar a aquisição de recursos formais, apropriados e específicos para viabilizar a participação dos alunos na interação. Além disso, a professora favorece a ampliação do conhecimento sobre o que é adequado falar e com quem e promove o desenvolvimento de recursos que permitem a distinção entre oralidade e letramento. Ao conceder a palavra aos alunos, a professora implementa estratégias de envolvimento, permitindo que os alunos falem, e ratificando-os incentiva-os a manifestar-se. Ficou claro que as ações de scaffolding podem contribuir para o desenvolvimento da competência comunicativa do aluno e de sua consciência crítica das diferenças lingüísticas, pois ao fornecer modelos 


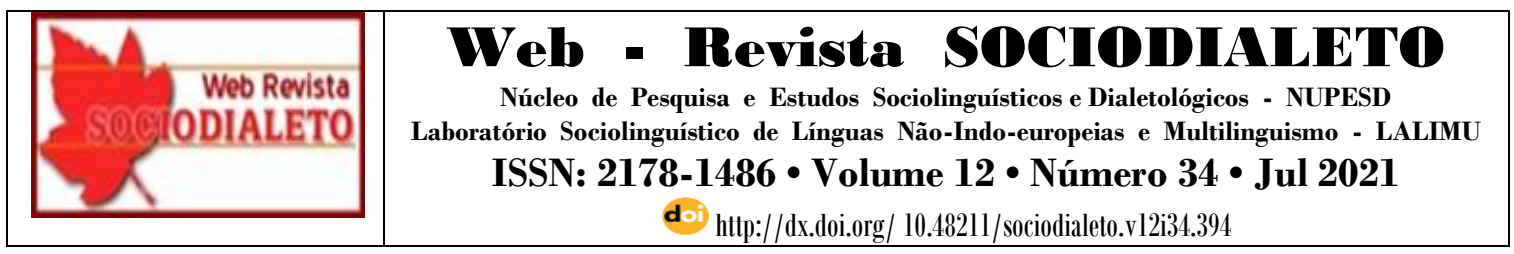

de estilos monitorados, a professora propicia aos alunos o contato com a variedade de prestígio da língua, possibilitando saber quando e como usar esses estilos.

\section{REFERÊNCIAS}

BORTONI-RICARDO, Stella Maris. Educação em língua materna - a sociolingüística na sala de aula. São Paulo: Parábola Editorial, 2004.

BORTONI-RICARDO, Stella Maris. Nós cheguemos na escola, e agora? Sociolingüística \& Educação. São Paulo: Parábola Editorial, 2005, p. 15, 61.

BORTONI-RICARDO, Stella Maris. O professor pesquisador: introdução à pesquisa qualitativa. São Paulo: Parábola Editorial, 2008, p.49.

BORTONI-RICARDO, S. M. e SOUSA. M. A. F. Andaimes e pistas de contextualização. Um estudo do processo interacional em uma sala de alfabetização. In: TACCA, M. C. V. (Org.). Aprendizagem e trabalho pedagógico. Campinas: Alínea, 2006.

BORTONI-RICARDO, S. M. e DETTONI, R. Diversidades lingüísticas e desigualdades sociais. In: COX, M. I. P; ASSIS-PETERSON, A. A. de. (orgs.). Cenas de sala de aula. Campinas: Mercado de Letras, 2001, p. 81-103.

CAJAL, I. B. A interação de sala de aula: como o professor reage às falas iniciadas pelos alunos? In: COX, M. I. P; ASSIS-PETERSON, A. A. de. (orgs.). Cenas de sala de aula. Campinas: Mercado de Letras, 2001, p. 125-159.

CAZDEN. Classroom Discourse: the language of teaching and learning. Portsmouth: Heinemann, 1988.

CHOMSKY, N. Aspects of the theory of syntax. Cambridge Mass: Mit Press, 1965, p. 83.

COOK-GUMPERZ, J. Toward a Sociolinguistics of Education. Berkeley: University of Califórnia. 1987.

DETTONI, R. do V. A interação em sala de aula: as crenças e práticas do professor. Tese de mestrado inédita, Universidade de Brasília, 1995.

ERICKSON, F. Ethnographic description. In: Sociolinguistics. Berlim/Nova York: Walter de Gruyter, 1988, p. 81.

ERICKSON, F. Transformation and school Sucess: the Politics and Culture of Educational Achievement. Antropology \& Education Quaterly. Vol. 18, nº 4. 1987.

HYMES, Dell H. On Communicative Competence. In: PRIDE, J. B. \& HOLMES, S. (orgs.). Sociolinguistics. Harmondsworth: Peguin Books, 1972, p. 271.

HYMES, Dell H. Introduction. In: CAZDEN, C., JOHN, V E HYMES, D. (orgs.). Functions of language in the classroom. New York: Teachers College, 1972. 


\begin{tabular}{|c|c|}
\hline $\begin{array}{l}\text { Web } \\
\text { ODIA }\end{array}$ & 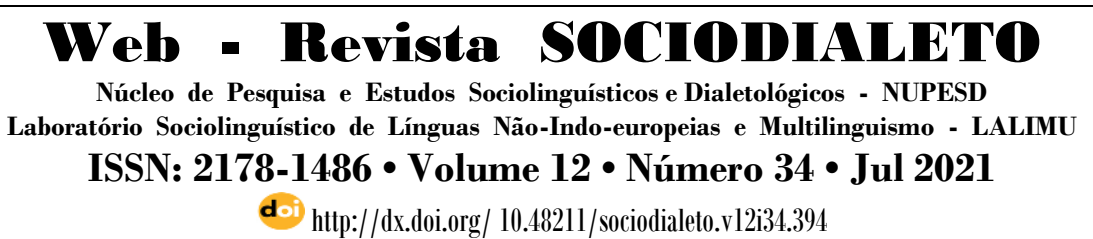 \\
\hline
\end{tabular}

HYMES, Dell H. Foundations of Sociolinguistics: an Etnographic Approach. Philadelphia: University of Pennsylvania Press, 1974.

LABOV, W. Language in the Inner City. Philadelphia: University of Pennsylvania Press. 1972.

LIMA, Maria da Glória Soares Barbosa. Os usos cotidianos de escrita e as implicações educacionais: uma etnografia. Teresina: EDUFPI, 1996. 142p.

TRAVÁGLIA, Luiz Carlos. Gramática e interação: uma proposta para o ensino de gramática no $1^{\circ}$ e $2^{\circ}$ graus. 8. Ed. São Paulo: Cortez, 2002, p. 17.

Recebido em: 22/04/2021 | Aprovado em: 15/05/2021. 